\title{
COLOMBIAN VANILLA AND ITS MICROBIOTA. III. DIVERSITY AND STRUCTURE OF THE ENDOPHYTIC COMMUNITY
}

\author{
M. A. Gambon-Gaitán ${ }^{1}$ and J. T. Otero-Ospina ${ }^{2}$ \\ ${ }^{1}$ Laboratorio de Biología Tropical, Departamento de Biología, Universidad Nacional de Colombia, \\ Carrera 30 \# 45-03, Bogotá, D. C., Colombia; E-mail: magamboaga@unal.edu.co \\ ${ }^{2}$ Grupo de Investigación en Orquídeas, Ecología y Sistemática Vegetal, Universidad Nacional de \\ Colombia, Carrera 32 \# 12-00, Palmira, Colombia; E-mail: jtoteroo@unal.edu.co
}

(Received 11 April, 2016; Accepted 15 June, 2016)

Endophytic fungal communities are well-recognised entities within plants worldwide. They hold species with potential in medicinal affairs, biological control of pests, industry, and more. Nevertheless, ecological data about structure and dynamics of endophytic communities are scarce. In this study we sampled root, stem and leaf tissues of Colombian vanilla species in order of both, identifying endosymbionts and characterising the community they belong to. An interesting array of endophytic species was found, including taxa that function as pathogens, saprotrophs, and dermatophytes in other plants/scenarios. Ecological parameters show a moderate diversity with a lognormal arrangement of species quite similar to communities of macroorganisms. Many species here reported belong to taxa broadly reported as sources of biologically active compounds, so they are good candidates for bioprospecting research.

Key words: Colletotrichum, endophytes, fungal ecology, Fusarium, tropical fungi, Vanilla, xylariaceous fungi

\section{INTRODUCTION}

Endosymbiotic communities of plants gained a lot of attention in recent years due to several factors. First, they are believed to be a very rich source of hidden biodiversity (Arnold et al. 2000), and it is expected that biological inventories will increase notably with new microbial species if more plants are studied in this regard. Second, endophytic communities seem to be assembled in the same way communities of macroorganisms are structured, so they are a useful model for ecological community research (and an easier one to 
work with, Gamboa and Bayman 2001). Third, quite important too, many microbial endophytes are believed to be source of metabolites with potential to be used in medicine, biological control, industry, etc. (Strobel and Long 1998).

A vast majority of plants has not been studied in terms of their endosymbiont communities, and many aspects of the natural history of endophytes are not known. Most studies to date have been performed, as predictable, on angiosperms, and typically studies on dicotyledonous plants are devoted to make the inventory of their endosymbionts and to establish both contribution to biodiversity and potential properties of endophytes (e.g. Arnold et al. 2001, Lodge et al. 1996, Petrini et al. 1982). On the other hand, most studies on monocots have been devoted to the grass-endophyte model in which mutualism has been the recurrent theme (Bacon and de Battista 1991, Clay 1988, Crawford et al. 2010, White Jr. 1987).

This paper deals with the endophytic community of vanillas, a group of climbing, tropical monocots, grouped in the genus Vanilla. Vanillas are the only edible orchids known to date, and about a hundred species are currently accepted (Soto-Arenas and Cribb 2010). Vanilla planifolia is an important aromatic crop that is propagated asexually, so its genetic base is narrow and it is prone to devastating infections by pathogenic microorganisms (Bory et al. 2008, Gamboa-Gaitán 2014, Ordóñez et al. 2012). Studying naturally-associated endosymbionts of Vanilla is important since endophytes have been broadly proposed as potential antagonists of disease-causing microorganisms, so they can play an important role in plant defence and biological control (Herre et al. 2007, Mejía et al. 2008, Otero et al. 2013).

This work was devoted to: 1) study the diversity of endophytic microorganism communities from both wild and cultivated Colombian vanillas, and 2) characterize these communities.

\section{MATERIALS AND METHODS}

Vanillas used in this study were Vanilla planifolia, V. calyculata, V. odorata, and four unidentified species from the Colombian Chocó region (Figs 1-2). Vouchers consist of photographs since specimens found were either too small or weak, and a greater sample would mean killing the individual (vanillas are very scarce, they have low densities and are an endangered group). Furthermore, wild individuals were all of them sterile. Isolation of endophytes was performed as published in Gamboa and Bayman (2001), and Gamboa et al. (2002). In brief, fresh, healthy plant tissues from roots, stems, and leaves were taken to the lab and washed externally with detergent and tap water. Although samples from diseased leaves and a fruit were surveyed too, they were not included in ecological analysis, and are only shown for registering 
its presence in vanillas. Superficial sterilisation was performed submerging tissues in ethanol 70\% (1 min), commercial hypochlorite 50\% (3 min), and ethanol 70\% (30 s). They were then washed in distilled water and cut into 4 $\mathrm{mm} \times 4 \mathrm{~mm}$ squares that were plated in Petri dishes containing potato-based growth medium (PDA: $20 \mathrm{~g}$ of potato dextrose agar Scharlau ${ }^{\circledR}$ in $1 \mathrm{~L}$ of water, autoclaved $15 \mathrm{~min}$ at $125{ }^{\circ} \mathrm{C}$ and $1.25 \mathrm{~kg} / \mathrm{cm}^{2}$ ). Cultures were kept at room temperature and observed daily. Growing mycelia were transferred to Petri dishes containing PDA as they emerged, and observed for further identification. Strains were transferred to malt extract agar (MEA) to induce sporulation or facilitate identification, as needed (MEA: $20 \mathrm{~g}$ of malt agar Scharlau ${ }^{\circledR}$ in $1 \mathrm{~L}$ of water, autoclaved $15 \mathrm{~min}$ at $125^{\circ} \mathrm{C}$ and $\left.1.25 \mathrm{~kg} / \mathrm{cm}^{2}\right)$. Purified strains were later transferred to potato dextrose broth (PDA without agar) and kept two weeks at room temperature and slow agitation. Mycelia were lyophilised at the Plant Physiology Laboratory at Universidad Nacional de Colombia-Bogotá, and sent to the Molecular Biology Laboratory at Pontificia
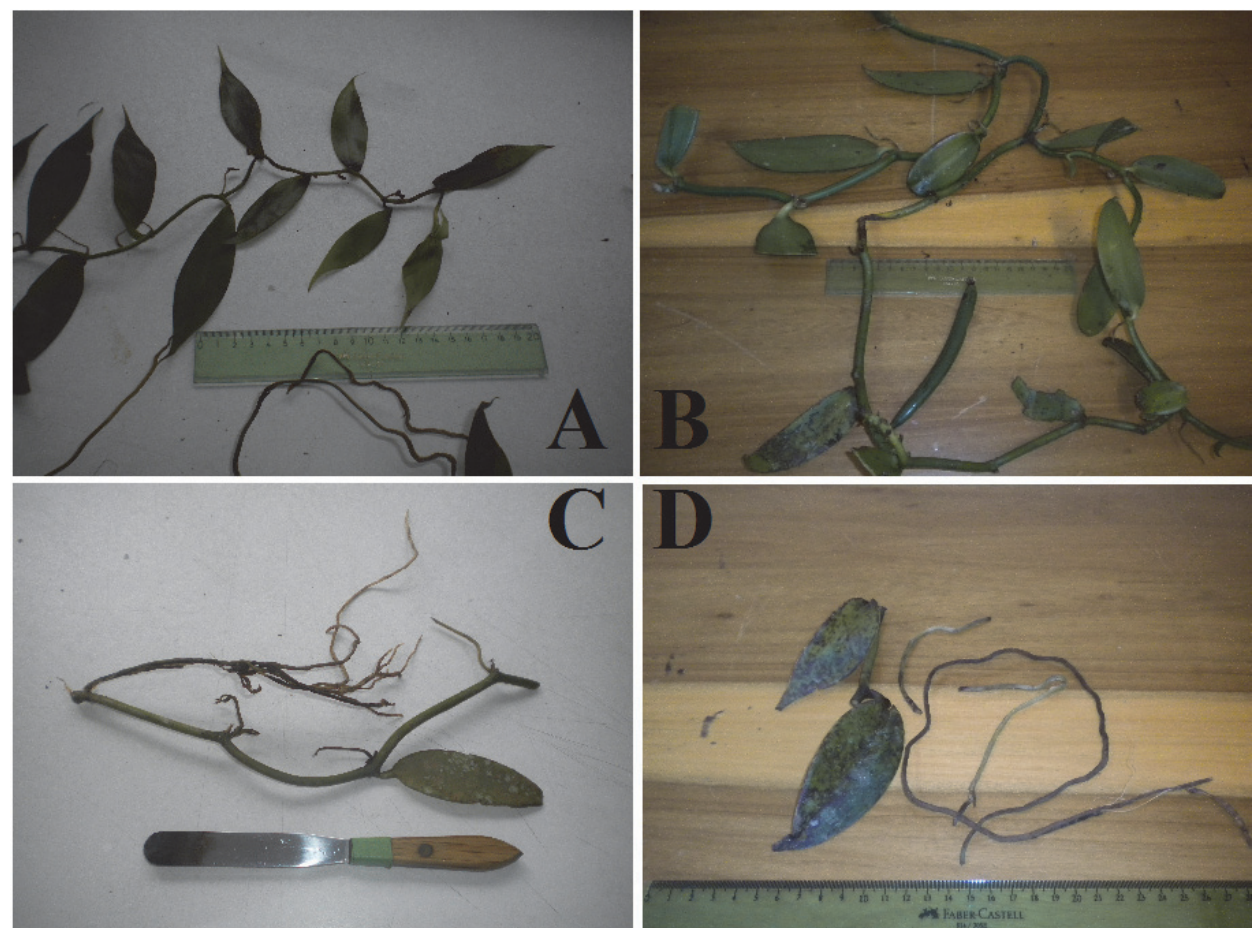

Fig. 1. Macroscopical view of some vanillas used in this study. $\mathrm{A}$ and $\mathrm{B}=$ vanillas from Bahía Málaga, courtesy of Néstor D. Jiménez, Universidad Nacional de Colombia-Bogotá; $\mathrm{C}$ and $\mathrm{D}=$ vanillas from Colombian Pacific coast courtesy of Nicola Flanagan, Pontificia Universidad Javeriana-Cali 
Universidad Javeriana-Cali for DNA extraction. Sequencing of the ITS region was performed at Macrogen (Korea). Microscopical observation, keys, fungal experts' advice, and ITS sequences were used for species identification. The term morphospecies is here used to refer to any isolated strain, even if its scientific name is not known.

Endophytic fungal communities were characterised using diversity indices of Shannon-Wiener $\left(\mathrm{H}^{\prime}\right)$, and evenness $\left(\mathrm{J}^{\prime}\right) \mathrm{H}^{\prime}$ (Krebs 1989, Zar 1999):

$$
H^{\prime}=-\sum_{i=1}^{k} p_{i} \log p_{i} \quad H_{\text {max }}^{\prime}=\log k \quad J^{\prime}=\frac{H^{\prime}}{H^{\prime}{ }_{\text {max }}}
$$

where $\mathrm{p}_{\mathrm{i}}$ is proportion of each morphospecies (number of individuals of that taxon over total number of isolated individuals), and $\mathrm{k}$ is number of categories, in this case, number of morphospecies. For estimating further community parameters, i.e. sampling effort and distribution patterns, species accumulation curves (curve showing species in a decreasing arrangement), and Preston octave's graph were made.
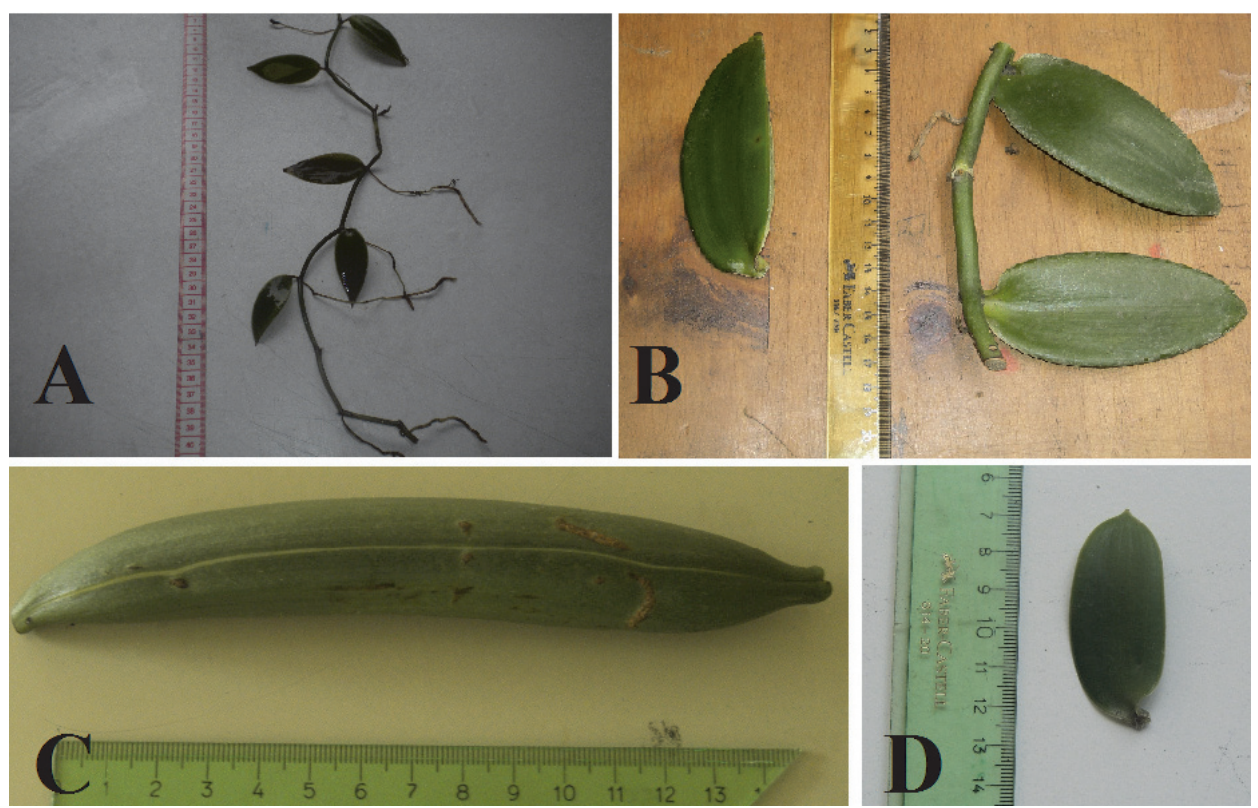

Fig. 2. Macroscopical view of some vanillas used in this study. $A=$ vanilla from Colombian Pacific coast courtesy of Nicola Flanagan, Pontificia Universidad Javeriana-Cali; B = cultivated vanilla (V. planifolia); $\mathrm{C}=$ wild vanilla (V. calyculata), from lowlands in Departamento del Valle, courtesy of Guillermo Reina; $\mathrm{D}=$ vanilla from private garden courtesy of professor Huertas, Universidad Nacional de Colombia-Palmira 


\section{RESULTS}

\section{General aspects}

In this study 1055 plant fragments that totalised 4,220 $\mathrm{mm}^{2}$ were sampled, and 56 morphospecies of endosymbiont microorganisms were found in tissues of seven species of Colombian vanillas (Table 1). Most morphospecies were fungi (54 out of 56) and included 13 mycelia sterilia. Additionally, one actinomycete and one Gram-negative bacterium were found. A total of 525 isolates yielded a community density of 1.3 species per $\mathrm{cm}^{2}$, while individual endophytic density was 0.124 microorganisms per $\mathrm{mm}^{2}$. The most frequent microorganism found was the Gram-negative bacterium, but neither this nor the actinomycetes were included in community characterisation analysis, since the objective of this report is to characterise the fungal endophytic community in vanillas.

All organs sampled, i.e. roots, stems, leaves and fruits, yielded endophytic microorganisms. Just two foliar epiphytes were identified: Biscogniauxia atropunctata (Xylariales) and Cosmospora sp. (Hypocreales), although they appeared as endophytes, too. Fungal taxa reported here are new records for endosymbiont mycoflora of vanillas, with the exception of Fusarium oxysporum and Colletotrichum gloeosporoides, which have already been reported as inhabitants of Vanilla (Gamboa-Gaitán 2013, Ordóñez-Castillo 2011, Ordóñez et al. 2012, Talubnak and Soytong 2010). Along with Alternaria alternata, Bionectria sp., and Colletotrichum boninense, those taxa are well recognised as plant pathogens, but all of them were recovered from healthy tissues here. From both healthy and diseased leaves Fusarium solani was isolated along with other yet unidentified species of Fusarium (Table 2).

\section{Community analysis}

Diversity, as measured by the Shannon-Wiener index was $\mathrm{H}^{\prime}=1.577701$, maximal diversity was $\mathrm{H}_{\max }^{\prime}=1.732393$ and evenness was $\mathrm{J}^{\prime}=0.91$. Cumulative curves of species abundance showed a pattern typical of lognormal distribution (Fig. 3), with few abundant species and many species with few individuals. Frequencies of observed number of species can be grouped in classes or octaves according to Preston $(1948,1962)$, and this study shows a tendency to a bimodal pattern of distribution (Fig. 4) of the endophytic fungal community. The modal octave is well included within distribution (2-4 octaves, Fig. 4).

\section{Fungal endophytes in Colombian vanillas}

Fifty-four taxa of endophytic fungi were recovered in this study. Sterile morphospecies are treated as either mycelia sterilia if no reproductive struc- 
ture and no somatic trait is notable for referring to them, or they are described by some phenotypic character like colour or texture (Tables 1 and 2). Most strains are stored at the Laboratorio de Biología Tropical ceparium. Although all morphospecies were grown in liquid medium and then lyophilised for DNA extraction and ITS sequence amplification, not all of them were successfully identified this way. Keys and fungal expert advice helped to assign names to species here presented.

Xylariaceous fungi were represented by Biscogniauxia atropunctata, Pestalotiopsis theae and Xylaria sp. These taxa were isolated from healthy stem and leaf tissues. Other conspicuous endosymbionts were dark septate endophytes (DSE) from roots, traditionally referred to as members of the Phialocephala spe-

Table 1

Endophytic microorganisms found in Colombian vanillas and their frequency. Some identifications are dubious $\left(^{*}\right)$. Proportion was calculated for fungi only

\begin{tabular}{lcc}
\hline Isolate & Frequency & Proportion $\left(p_{\mathrm{i}}\right)$ \\
\hline Actinomycetes & 3 & - \\
Alternaria sp. & 12 & 0.033 \\
Yellow & 8 & 0.022 \\
Yellow metallic & 2 & 0.005 \\
Arthrographis sp. & 11 & 0.031 \\
Aspergillus niger & 5 & 0.014 \\
Bacillus (Gram-) & 169 & - \\
Bionectria sp. & 10 & 0.028 \\
Biscogniauxia atropunctata & 8 & 0.022 \\
White 1 & 4 & 0.011 \\
White 2 & 18 & 0.050 \\
White 3 & 2 & 0.005 \\
White wetty (“Colletotrichum”) & 12 & 0.033 \\
Brown & 1 & 0.002 \\
Colletotrichum sp1 & 7 & 0.019 \\
Colletotrichum sp2 & 5 & 0.014 \\
Colletotrichum boninense & 9 & 0.025 \\
Colletotrichum gloeosporoides & 10 & 0.028 \\
Cosmospora sp. & 5 & 0.014 \\
Diaporthe eucalyptorum & 5 & 0.014 \\
Fusarium oxysporum & 12 & 0.033 \\
Fusarium solani & 26 & 0.073 \\
\hline & & \\
\hline
\end{tabular}




\section{Table 1 (continued)}

\begin{tabular}{|c|c|c|}
\hline Isolate & Frequency & Proportion $\left(p_{\mathrm{i}}\right)$ \\
\hline Grey greenish & 1 & 0.002 \\
\hline Cream-coloured & 5 & 0.014 \\
\hline Hypocrea lixii & 3 & 0.008 \\
\hline Hypocrea virens & 5 & 0.014 \\
\hline Lasiodiplodia sp. & 4 & 0.011 \\
\hline Lasiodiplodia venezuelensis & 3 & 0.008 \\
\hline Mycelia sterilia & 3 & 0.008 \\
\hline Mycelia sterilia 2 & 4 & 0.011 \\
\hline Mycelia sterilia 3 & 3 & 0.008 \\
\hline Mycelia sterilia 4 & 4 & 0.011 \\
\hline Mycelia sterilia 5 & 3 & 0.008 \\
\hline Mycelia sterilia 6 & 4 & 0.011 \\
\hline Mycelia sterilia 7 & 3 & 0.008 \\
\hline Mycelia sterilia 8 & 4 & 0.011 \\
\hline Mycelia sterilia 9 & 3 & 0.008 \\
\hline Mycelia sterilia 10 & 4 & 0.011 \\
\hline Mycelia sterilia 11 & 3 & 0.008 \\
\hline Mycelia sterilia 12 & 3 & 0.008 \\
\hline Mycelia sterilia 13 & 3 & 0.008 \\
\hline Kinky & 1 & 0.002 \\
\hline Kinky 2 & 1 & 0.002 \\
\hline Neofusicoccum sp. & 10 & 0.028 \\
\hline Penicillium sp. & 16 & 0.045 \\
\hline Pestalotia sp. & 11 & 0.031 \\
\hline Pestalotiopsis theae & 12 & 0.033 \\
\hline Phialocephala sp. (EOS)* & 15 & 0.042 \\
\hline Phomopsis sp. & 9 & 0.025 \\
\hline Rhizoctonia sp. & 1 & 0.002 \\
\hline Reddish ("Fusarium")* & 2 & 0.005 \\
\hline Trichoderma sp. & 13 & 0.036 \\
\hline Trichoderma harzianum & 11 & 0.031 \\
\hline Volutella sp. & 3 & 0.008 \\
\hline Xylaria sp. & 5 & 0.014 \\
\hline Total & 525 (fungi 353) & \\
\hline
\end{tabular}


cies complex. Two more species complexes already mentioned are Fusarium and Colletotrichum. Two forma specialis of F. oxysporum were identified: loti and melonis. Additionally, F. solani and a strain from a sick leaf, probably $F$. oxysporum f. sp. vanillae (Table 2), were isolated, too. On the other hand, Colletotrichum was present in both healthy and sick tissues of leaves and stems: $C$.

Table 2

Endophytes in Colombian vanillas showing organs in which they were found and possible role according to literature

\begin{tabular}{|c|c|c|c|}
\hline Microorganism & Species & Tissue & Role suggested \\
\hline Alternaria alternata & V. planifolia & leaf, root & pathogen \\
\hline Arthrographis sp. & Vanilla sp. & root & human pathogen \\
\hline Aspergillus niger & Vanilla sp. & stem & endophyte, saprotroph \\
\hline Bacterium (bacilo Gram-) & $V$. planifolia & leaf & $?$ \\
\hline Bionectria sp. & $V$. odorata & leaf & pathogen \\
\hline Biscogniauxia atropunctata & Vanilla sp. & leaf epiphyte & $\begin{array}{l}\text { saprotroph, epiphyte, } \\
\text { pathogen }\end{array}$ \\
\hline Colletotrichum boninense & $V$. planifolia & stem & pathogen \\
\hline Colletotrichum gloeosporioides & V. planifolia & leaf & endophyte, pathogen \\
\hline Colletotrichum sp. & $\begin{array}{l}\text { V. planifolia, } \\
\text { Vanilla sp. }\end{array}$ & $\begin{array}{l}\text { sick leaf, healthy } \\
\text { leaf, stem }\end{array}$ & endophyte \\
\hline Cosmospora sp. & Vanilla sp. & leaf & $\begin{array}{c}\text { epiphyte, polyphyletic, } \\
\text { volutella? }\end{array}$ \\
\hline Diaporthe eucalyptorum & Vanilla sp. & stem & pathogen \\
\hline Fusarium oxysporum f. sp. loti & V. odorata & leaf & pathogen \\
\hline $\begin{array}{l}\text { Fusarium oxysporum f. sp. } \\
\text { melonis }\end{array}$ & V. planifolia & leaf & pathogen \\
\hline Fusarium solani & V. planifolia & $\begin{array}{c}\text { sick leaf, } \\
\text { healthy leaf }\end{array}$ & pathogen \\
\hline Fusarium solani & V. calyculata & root fruit & pathogen \\
\hline $\begin{array}{l}\text { Fusarium sp. (probably F. } \\
\text { oxysporum f. sp. vanillae) }\end{array}$ & $V \cdot$ planifolia & sick leaf & \\
\hline \multicolumn{4}{|l|}{ Pathogen endophyte } \\
\hline Fusarium sp. & V. odorata & leaf & endophyte \\
\hline Fusarium sp. & Vanilla spp. & stem, root & endophyte \\
\hline Hypocrea virens & Vanilla sp. & stem & saprotroph \\
\hline Lasiodiplodia venezuelensis & Vanilla sp. & stem & pathogen, endophyte \\
\hline Mycelia sterilia & Vanilla spp. & leaf, stem, root & endophyte \\
\hline Neofusicoccum sp. & V. calyculata & fruit, leaf & pathogen \\
\hline
\end{tabular}


Table 2 (continued)

\begin{tabular}{|c|c|c|c|}
\hline Microorganism & Species & Tissue & Role suggested \\
\hline Penicillium spp. & V. odorata & leaf & endophyte \\
\hline Penicillium spp. & Vanilla spp. & stem, root & endophyte \\
\hline Pestalotia sp. & V. planifolia & sick leaf & endophyte, pathogen \\
\hline Pestalotia sp. & V. calyculata & healthy leaf & endophyte, pathogen \\
\hline Pestalotia sp. & Vanilla sp. & fruit & endophyte, pathogen \\
\hline Pestalotiopsis theae & Vanilla sp. & leaf & \\
\hline Phialocephala sp. & $\begin{array}{l}\text { V. odorata } \\
\text { Vanilla sp. }\end{array}$ & root & endophyte \\
\hline Phomopsis sp. & $\begin{array}{l}\text { V. planifolia, } \\
\text { Vanilla sp. }\end{array}$ & root & pathogen, endophyte \\
\hline Rhizoctonia sp. & Vanilla sp. & root & $\begin{array}{c}\text { pathogen, endophyte, } \\
\text { mycorrhiza }\end{array}$ \\
\hline Trichoderma harzianum & $V$. planifolia & root & saprotroph \\
\hline Trichoderma sp. & V. odorata & leaf & endophyte \\
\hline Trichoderma sp. & Vanilla spp. & stem, root & endophyte \\
\hline Volutella sp. & Vanilla sp. & leaf & pathogen \\
\hline Xylaria spp. & $V$. planifolia & sick leaf & saprotroph, endophyte \\
\hline Xylaria spp. & Vanilla spp. & root & saprotroph, endophyte \\
\hline
\end{tabular}

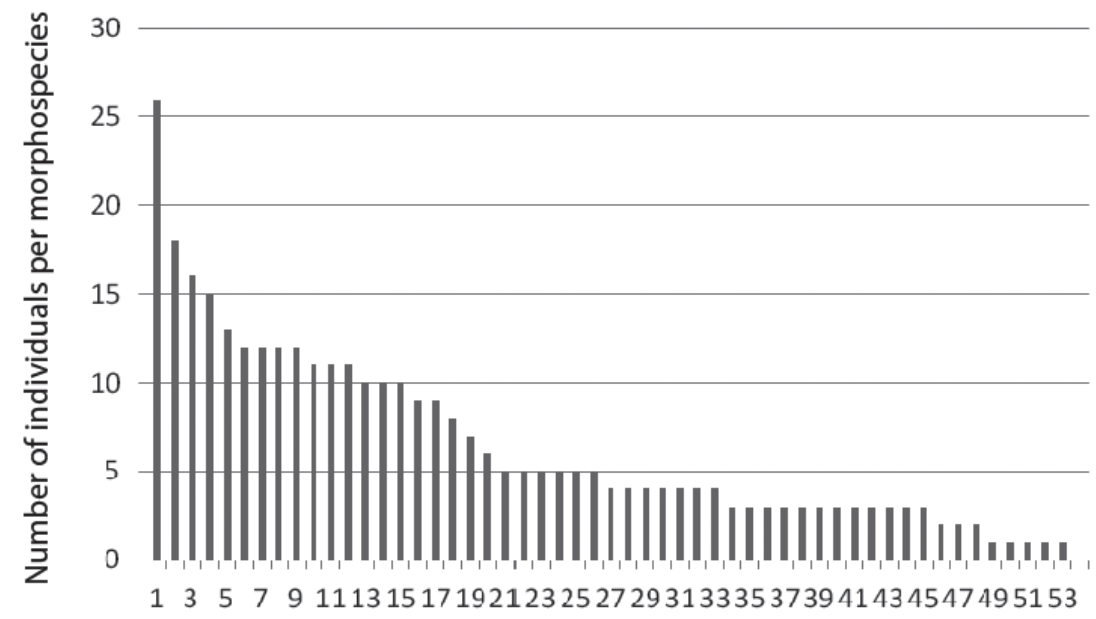

Morphospecies arranged by decreasing number of individuals

Fig. 3. Community structure of fungal endophytic morphospecies from vanillas. Few species are abundant while most taxa are represented by few individuals 
gloeosporoides and C. boninense, plus an unidentified strain. Two anamorphic fungi Aspergillus niger and a triverticilated Penicillium were found as endophytes, too.

Hypocreales fungi were represented by Bionectria sp., Cosmospora sp., Hypocrea virens, H. lixii and its anamorph Trichoderma harzianum. Volutella sp., anamorphic state of Pseudonectria, was found, too. Among Botryosphaeriales we found Lasiodiplodia and Neofusicoccum. Other groups of vanilla endophytes here reported are Arthrographis (Eurotiales), Diaporthe eucalyptorum (Diaporthales) and Alternaria alternata (Pleosporales). All of them were isolated from healthy tissues along with the most common endosymbiont here isolated, a Gram-negative bacillus.

\section{DISCUSSION}

This study was performed on vanillas collected from southwest Colombia, and both wild and cultivated vanillas were sampled. Vanilla planifolia, $V$. calyculata, $V$. odorata and four unidentified species were employed. This report is novel in two aspects: it represents the first inventory of endosymbiont microorganisms of vanillas and it is the first attempt to characterise the endophytic fungal community in genus Vanilla. Given that vanilla density in the wild is so low, it was possible to obtain samples of more than one individual only from cultivated vanillas. This is why we present the analysis of the fungal community of vanillas as a unit.

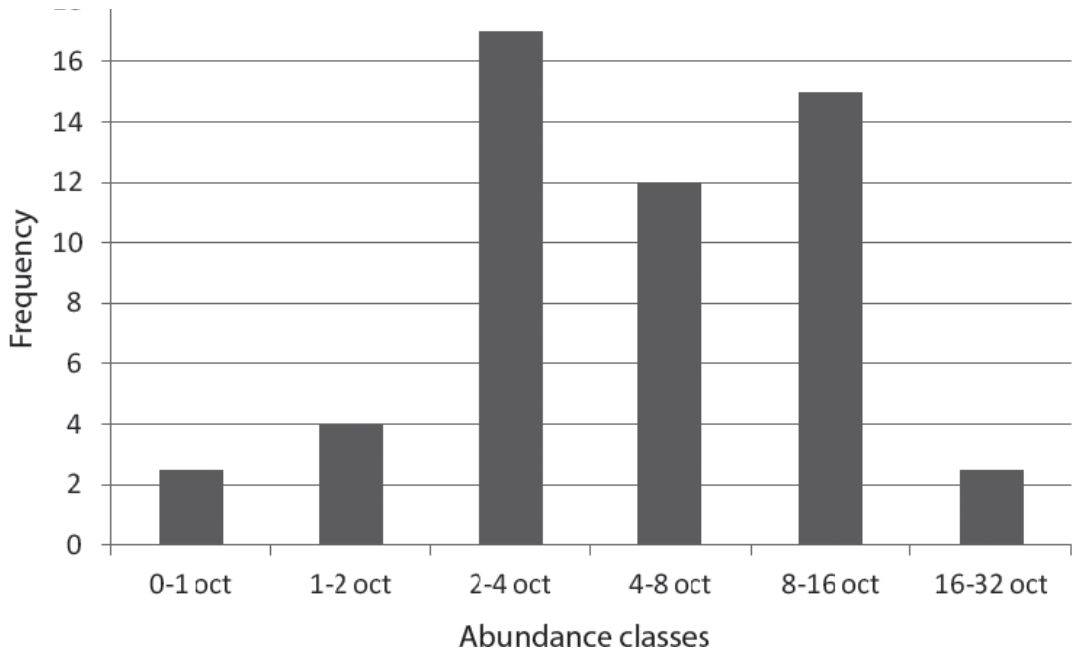

Fig. 4. Frequency of observed number of species grouped in abundance classes (Preston octaves). There is a tendency to a bimodal pattern of distribution and the modal octave (2-4 octaves) is well included in distribution 
General aspects

The number of morphospecies found (54 fungi, one actinomycetes and one bacillus, Table 1) is similar to other records in tropical and subtropical plants. For example cultivated vanillas (55 morphospecies, Ordóñez-Castillo 2011), Guarea guidonia (38 morphospecies, Gamboa and Bayman 2001), Opuntia humifusa (17 morphospecies, Silva-Hughes et al. 2015) and adds evidence to the hypothesis that all plant species harbour endosymbionts in healthy tissues. Presence of many unidentified species, including 13 mycelia sterilia, also adds support to the hypothesis that tropical plants can be considered hot spots of biodiversity due to their cryptic endosymbiont microbiota (Arnold et al. 2000). Although PDA was the only growth medium used for endophyte isolation, an important amount of endosymbionts was recovered and this supports the idea that a diversification of both sampling methods and growing techniques are needed for better sampling and understanding endophytic communities (Gamboa-Gaitán 2006).

\section{Community analysis}

Diversity index $\left(\mathrm{H}^{\prime}=1.57\right)$ was low for fungal endophytes of vanilla as compared to other tropical plant in which the same index was used for studying endophytic fungi: $\mathrm{H}^{\prime}=3.18$ (Gamboa and Bayman 2001). Nevertheless, maximal diversity $\left(\mathrm{H}_{\max }^{\prime}=1.73\right)$ is close to $\mathrm{H}^{\prime}$ and can be interpreted as undersampling was low. This is also supported by Preston octaves graph (Fig. 4), which shows modal octave well placed within distribution. Given that evenness was high $\left(\mathrm{J}^{\prime}=0.91\right.$, maximal value is 1.0$)$, it is obvious to ask why diversity appears so low in this community. A possible answer is that the most common endophyte, a Gram-negative bacillus, was not included in community analysis. In fact, this bacterium was present in one third of vanilla fragments that were plated and it showed the ability of restricting fungal growth (other than Fusarium). Possible fungistatic effects of this bacterium are not known, and using other artificial growing media that exclude it could lead to a higher number of fungal isolates. Comparing endophytic fungal communities of vanillas from this study with those of other plants, such as Guarea guidonia, requires caution. Vanillas are tropical climbing monocot herbs, while G. guidonia is a dicot tree that can reach $30 \mathrm{~m}$ tall. Although diversity index was much higher in G. guidonia, evenness is higher in vanilla and this is difficult to interpret. A tree $30 \mathrm{~m}$ tall spans a more variable range of environments than climbing vanillas that are restricted to the understory. Vertical stratification of trees in terms of their endosymbiont community has already been demonstrated (Gamboa and Bayman 2001, Lodge et al. 1996). 
Finding few abundant species of endophytic fungi and more species with few individuals, indicates a lognormal distribution of species, typical of macroorganism communities that was already found for endophytes in a tropical timber tree (Guarea guidonia, Gamboa and Bayman 2001). This is the first report of a fungal endosymbiont community structure for a tropical monocot.

\section{Fungal endophytes in Colombian vanillas}

The fungal endophytic community found here shows a very interesting composition and most species are new records of vanilla endophytes (Tables 1 and 2). A study with cultivated vanillas (Ordóñez-Castillo 2011, Ordóñez et al. 2012), showed a few genera in common but there is no species overlap. The inclusion of wild vanillas made it possible to get data from preserved habitats that are richer in biodiversity than commercial plantations. This implies that the inoculum source is more diverse and this is essential for obtaining greater fungal diversity in terms of both richness and variety (Rodrigues 1994, Gamboa and Bayman 2001).

Xylariaceous fungi are common endophytic inhabitants of plants (Petrini et al. 1995) and they were represented in this study by Biscogniauxia atropunctata, Pestalotiopsis theae and Xylaria sp. These taxa were isolated from healthy stem and leaf tissues although the first two taxa are mostly reported as plant pathogens. In fact, B. atropunctata is a pathogen in oaks (Williamson 2010) and $P$. theae is the causal agent of tea gray blight (Yang and Zhang 2012). Xylaria spp. are mostly reported as endophytes or saprotrophs (Gamboa and Bayman 2001, Lodge et al. 1996, Taylor et al. 1999). One of the most intriguing aspects of fungal endophytes is the fact that they can be completely asymptomatic in a plant species and pathogenic to other plants or even to a species of another kingdom (Coccidioides posadasii, Sporothrix schenckii, Arnold 2007). We found Arthrographis, a genus in which notorious dermatophyte species have been reported (Sugiura and Hironaga 2010).

Dark septate endophytes (DSE) are conspicuous endosymbionts commonly found as endophytes, especially in roots, and they have traditionally been assigned to the Phialocephala species complex (Sieber and Grünig 2006). This is particularly true for temperate species; almost nothing is known about tropical DSE. Two more important species complex were found as vanilla endophytes: Fusarium and Colletotrichum. Fusarium was present as F. oxysporum with two forma specialis: loti and melonis. Additionally, F. solani and a strain from a diseased leaf, probably F. oxysporum f. sp. vanillae, were isolated, too. The presence of Fusarium as both endophyte and pathogen has been well documented (Bacon and Yates 2006), and we report here and elsewhere (Gamboa-Gaitán 2013) both roles for Fusarium species in vanillas. Another important species complex is Colletotrichum, here represented by C. gloeosporoides and C. boninense, plus an 
unidentified strain. Again, taxa were recovered from both healthy and sick tissues of leaves and stems. Both complexes C. gloeosporoides and C. boninense are cited as endophytes and anthracnose-causing agents (Damm et al. 2012), but they were not recorded as disease causing agents in vanilla here.

Two anamorphic fungi well recognised as cosmopolitan species were isolated as vanilla endophytes: Aspergillus niger and a triverticillate Penicillium. Hypocreales fungi were represented by Bionectria sp., Cosmospora sp., Hypocrea virens, $H$. lixii and its anamorph Trichoderma harzianum. This taxon was reported as antagonistic to Fusarium oxysporum (Naik et al. 2010), but such a property was not recorded here. Similarly, Danielsen and Jensen (1999), did not find an inhibitory action of Trichoderma against $F$. verticillioides, so it appears that the role of this taxon in biological control awaits further confirmation. Volutella sp. is an anamorphic state of Pseudonectria that is commonly reported as a plant pathogen (Douglas 2008), and it was found asymptomatic here, too. Other plant pathogenic fungi that appeared asymptomatic here are two genera of Botryosphaeriales: Lasiodiplodia and Neofusicoccum. Other vanilla endophytes here reported are Arthrographis (Eurotiales), Diaporthe eucalyptorum (Diaporthales) and Alternaria alternata (Pleosporales). All of them were isolated from healthy tissues; vanillas appear to harbour them without any disease symptoms.

The most common endosymbiont of vanillas here isolated was a Gramnegative bacillus (Table 1). Bacteria are well-recognised endosymbiont microorganisms of plants (Chanway 1996), including vanillas (White Jr. et al. 2014), and the one found here was isolated from all organs sampled: roots, stems, and leaves. Some filamentous fungi growing in the vicinity of this bacterium were inhibited when they entered in contact with it, and this could be a consequence of compounds produced by this bacillus. It is clear that this bacterium deserves further studies. Endophytic microbes are well recognised as a potential source of bioactive compounds (Strobel 1996, Strobel and Long 1998), and many taxa here reported have also been recognised in this regard: Hypocrea (Trichoderma), Cosmospora, Bionectria, Fusarium spp., Aspergillus niger, Trichoderma spp., xylariaceous fungi, Colletotrichum spp., etc. (Tables 1 and 2). Thus, next obvious step in this research is bioprospecting this notable set of endosymbionts. They could also be the source of some metabolites found in vanillas that contribute to the flavour and aroma.

Acknowledgements - Many people helped us with logistics, to all of them many thanks: professor Huertas, Héctor K. Chávez, Miguel Tascón, Guillermo Reina and Fernando Ramos (Universidad Nacional de Colombia, Palmira campus); Nicola Flanagan (Pontificia Universidad Javeriana, Cali campus); Philip Silverstone-Sopkin (CUVC herbarium, Universidad 
del Valle); Luz Marina Melgarejo, Carolina Becerra, Julio Betancur y Néstor D. Jiménez (Universidad Nacional de Colombia, Bogotá campus); Paul Bayman (University of Puerto Rico). Funding was provided by Grupo de Investigación en Orquídeas y Ecología Vegetal, and División de Investigaciones de la Universidad Nacional de Colombia, Palmira campus (DIPAL) and Bogotá campus (DIB). Comments from anonymous reviewers were very useful, too.

\section{REFERENCES}

Arnold, A. E. (2007): Understanding the diversity of foliar endophytic fungi: progress, challenges, and frontiers. - Fungal Biol. Rev. 21: 51-66. http://dx.doi.org/10.1016/j. fbr.2007.05.003

Arnold, A. E., Maynard, Z. and Gilbert, G. S. (2001): Fungal endophytes in dicotyledonous neotropical trees: patterns of abundance and diversity. - Mycol. Res. 105(12): 15021507. http://dx.doi.org/10.1017/s0953756201004956

Arnold, A. E., Maynard, Z., Gilbert, G. S., Coley, P. D. and Kursar, T. A. (2000): Are tropical fungal endophytes hyperdiverse? - Ecol. Letters 3: 267-274. http://dx.doi.org/10.1046/ j.1461-0248.2000.00159.x

Bacon, C. W. and de Battista, J. (1991): Endophytic fungi of grasses. - In: Arora, D. K. et al. (eds): Handbook of applied mycology. Soil and plants. Vol. 1. Marcel Dekker, New York, pp. 231-256.

Bacon, C. W. and Yates, I. E. (2006): Endophytic root colonization by Fusarium species: histology, plant interactions, and toxicity. - In: Schulz, B., Boyle, C. and Sieber, T. (eds): Microbial root endophytes. Soil Biology Series. Springer, Berlin, pp. 133-152. http://dx.doi. org/10.1007/3-540-33526-9_8

Bory, S., Lubinsky, P., Risterucci, A. M., Noyer, J. L., Grisoni, M., Duval, M. F. and Besse, P. (2008): Patterns of introduction and diversification of Vanilla planifolia (Orchidaceae) in Reunion island (Indian Ocean). - Amer. J. Bot. 95(7): 805-815. http://dx.doi. org/10.3732/ajb.2007332

Chanway, C. P. (1996): Endophytes: they're not just fungi! - Can. J. Bot. 74: 321-322. http:// dx.doi.org/10.1139/b96-040

Clay, K. (1988): Fungal endophytes of grasses: a defensive mutualism between plants and fungi. - Ecology 69: 10-16. http://dx.doi.org/10.2307/1943155

Crawford, K. M., Land, J. M. and Rudgers, J. A. (2010): Fungal endophytes of native grasses decrease insect herbivore preference and performance. - Oecologia 164: 431-444. http://dx.doi.org/10.1007/s00442-010-1685-2

Damm, U., Cannon, P. F., Woudenberg, J. H. C., Johnston, P. R., Weir, B. S., Tan, Y. P., Shivas, R. G. and Crous, P. W. (2012): The Colletotrichum boninense species complex. - Studies in Mycology 73: 1-36. http://dx.doi.org/10.3114/sim0002

Danielsen, S. and Jensen, D. F. (1999): Fungal endophytes from stalks of tropical maize and grasses: isolation, identification, and screening for antagonism against Fusarium verticillioides in maize stalks. - Biocontrol Sci. Technol. 9(4): 545-553. http://dx.doi. org/10.1080/09583159929505

Douglas, S. M. (2008): Volutella blight of Pachysandra. - <<http://www.ct.gov/caes/lib/ caes/documents/publications/fact_sheets/plant_pathology_and_ecology/volutella_ blight_of_pachysandra_04-10-08r.pdf $\gg>$ (Retrieved 05.09.2015).

Gamboa-Gaitán, M. A. (2006): Hongos endófitos tropicales: conocimiento actual y perspectivas. - Acta Biol. Colomb. 11S: 3-20. 
Gamboa-Gaitán, M. A. (2013): Colombian vanilla and its microbiota. I. First report of Fusarium taxa from both wild and cultivated species. - Acta Bot. Hung. 55(3-4): 239-245. http://dx.doi.org/10.1556/abot.55.2013.3-4.6

Gamboa-Gaitán, M. A. (2014): Colombian vanilla and its microbiota. II. Diversity, culture and endophytic microorganisms. - Univ. Sci. 19(3): 287-300. http://dx.doi. org/10.11144/javeriana.sc19-3.vcmd

Gamboa, M. A. and Bayman, P. (2001): Communities of endophytic fungi in leaves of a tropical timber tree (Guarea guidonia: Meliaceae). - Biotropica 33(2): 352-360. http:// dx.doi.org/10.1646/0006-3606(2001)033[0352:coefil]2.0.co;2

Gamboa, M. A., Laureano, S. and Bayman, P. (2002): Measuring diversity of endophytic fungi in leaf fragments: does size matter? - Mycopathologia 156(1): 41-45. http:// dx.doi.org/10.1023/a:1021362217723

Herre, E. A., Mejía, L. C., Kyllo, D. A., Rojas, E., Maynard, Z., Butler, A. and van Bael, S. A. (2007): Ecological implications of anti-pathogen effects of tropical fungal endophytes and mycorrhizae. - Ecology 88(3): 550-558. http://dx.doi.org/10.1890/05-1606

Krebs, C. J. (1989): Ecological methodology. - Harper Collins, New York.

Lodge, D. J., Fisher, P. J. and Sutton, B. C. (1996): Endophytic fungi of Manilkara bidentata leaves in Puerto Rico. - Mycologia 88: 733-738. http://dx.doi.org/10.2307/3760967

Mejía, L. C., Rojas, E. I., Maynard, Z., van Bael, S., Arnold, A. E., Hebbar, P., Samuels, G. J., Robbins, N. and Herre, E. A. (2008): Endophytic fungi as biocontrol agents of Theobroma cacao pathogens. - Biol. Control 46: 4-14. http://dx.doi.org/10.1016/j.biocontrol.2008.01.012

Naik, G. B., Nagaraja, R., Basavaraja, M. K. and Naik, K. R. (2010): Variability studies of Fusarium oxysporum f. sp. vanillae isolates. - Int. J. Sci. Nature 1(1): 12-16.

Ordóñez-Castillo, N. F. (2011): Efecto de hongos endófitos en orquídeas del grupo Rhizoctonia y otros endófitos cultivables sobre el desarrollo de plantas de Vanilla planifolia Andrews. Tesis de maestría, Facultad de Ciencias Agropecuarias, Sede Medellín, Universidad Nacional de Colombia.

Ordóñez, N. F., Otero, J. T. and Díez, M. C. (2012): Hongos endófitos de orquídeas y su efecto sobre el crecimiento en Vanilla planifolia Andrews. - Acta Agronómica 61(3): 283-291.

Otero, J. T., Mosquera, A. T. and Flanagan, N. S. (2013): Tropical orchid mycorrhizae: potential applications in orchid conservation, commercialization, and beyond. - Lankesteriana 13(1-2): 57-63. http://dx.doi.org/10.15517/lank.v0i0.11537

Petrini, O., Petrini, L. E. and Rodrigues, K. F. (1995): Xylariaceous endophytes: an exercise in biodiversity. - Fitopatol. Brasil. 20: 531-539.

Petrini, O., Stone, J. and Carroll, F. E. (1982): Endophytic fungi in evergreen shrubs in western Oregon: a preliminary study. - Can. J. Bot. 60: 789-796. http://dx.doi.org/10.1139/ b82-102

Preston, F. W. (1948): The commonness, and rarity, of species. - Ecology 29: 254-283. http:// dx.doi.org/10.2307/1930989

Preston, F. W. (1962): The canonical distribution of commonness and rarity. Parts 1-2. Ecology 43: 185-215, 410-432. http://dx.doi.org/10.2307/1931976, http://dx.doi. org/10.2307/1933371

Rodrigues, K. F. (1994): The foliar fungal endophytes of the Amazonian palm Euterpe oleracea. - Mycologia 86: 376-385. http://dx.doi.org/10.2307/3760568

Sieber, T. N. and Grünig, C. R. (2006): Biodiversity of fungal root-endophyte communities and populations, in particular of the dark septate endophyte Phialocephala fortinii s. l. - In: 
Schulz, B., Boyle, C. and Sieber, T. (eds): Microbial root endophytes. Soil Biology Series. Springer, Berlin, pp. 107-132. http://dx.doi.org/10.1007/3-540-33526-9_7

Silva-Hughes, A. F., Wedge, D. E., Cantrell, C. L., Carvalho, C. R., Pan, Z., Moraes, R. M., Madoxx, V. L. and Rosa, L. H. (2015): Diversity and antifungal activity of the endophytic fungi associated with the native medicinal cactus Opuntia humifusa (Cactaceae) from the United States. - Microbiol. Res. 175: 67-77. http://dx.doi.org/10.1016/j. micres.2015.03.007

Soto-Arenas, M. A. and Cribb, P. (2010): A new infrageneric classification and synopsis of the genus Vanilla Plum. ex Mil. (Orchidaceae: Vanillinae). - Lankesteriana 9(3): 355398. http://dx.doi.org/10.15517/lank.v0i0.12071

Strobel, G. (1996): Endophytic fungi: new sources for old and new pharmaceuticals. - Pharmaceutical News 3: 7-9.

Strobel, G. A. and Long, D. M. (1998): Endophytic microbes embody pharmaceutical potential. - ASM News 64: 263-268.

Sugiura, Y. and Hironaga, M. (2010): Arthrographis kalrae, a rare causal agent of onychomycosis, and its occurrence in natural and commercially available soils. - Med. Mycol. 48(2): 384-389. http://dx.doi.org/10.3109/13693780903219014

Talubnak, C. and Soytong, K. (2010): Biological control of vanilla anthracnose using Emericella nidulans. - J. Agric. Technol. 6(1): 47-55.

Taylor, J. E., Hyde, K. D. and Jones, E. B. G. (1999): Endophytic fungi associated with the temperate palm Trachycarpus fortunei, within and outside its natural geographic range. - New Phytol. 142: 335-346. http://dx.doi.org/10.1046/j.1469-8137.1999.00391.x

White Jr., J. F. (1987): Widespread distribution of endophytes in the Poaceae. - Plant Disease 71: 340-342. http://dx.doi.org/10.1094/pd-71-0340

White Jr., J. F., Torres, M. S., Sullivan, R. F., Jabbour, R. E., Chen, Q., Tadych, M., Irizarry, I., Bergen, M. S., Havkin-Frenkel, D. and Belanger, F. C. (2014): Occurrence of Bacillus amyloliquefaciens as a systemic endophyte of vanilla orchids. - Microscopy Res. Techn. 77(11): 874-885. http://dx.doi.org/10.1002/jemt.22410

Williamson, J. (2010): Hypoxylon canker. - <<http://www.clemson.edu/extension/hgic/ tyk/2011/pdf/tyk0111.pdf $>>$ (Retrieved 05.09.2015).

Yang, X. and Zhang, H. (2012): Synergistic interaction of tea saponin with mancozeb against Pestalotiopsis theae. - Crop Protection 40: 126-131. http://dx.doi.org/10.1016/j. cropro.2012.04.013

Zar, J. H. (1999): Biostatistical analysis. 4 ed. - Prentice Hall, Upper Saddle River, NJ, E.U.A. 